\title{
The Great Polarization: Understanding to The Historical Shift Away from Social Action Within Evangelicalism
}

\author{
Benjamin Elliott ${ }^{1) *}$ \\ 1) Deer Park Alliance Church Red Deer, Alberta, Canada \\ ${ }^{*}$ Correspondent author: benelliott@deerparkchurch.ca
}

Received: 25 May 2021/ Accepted: 27 September 2021/ Published: Ol October 2021

\begin{abstract}
The goal of this paper is to discuss the enduring shift of the evangelical church, and in particular the Christian and Missionary Alliance Church as a case study, away from active social action in the late nineteenth century and towards more hesitant involvement through the twentieth century and up to the present. Following Timothy Moberg, this paper recognizes a significant reversal of emphasis in evangelicalism during this season, but argues that the root of this shift was not simply a change in focus but actual a great polarization of the ground of thought within the church. The paper involves a brief survey of some of the involved historical dynamics at play from Schleiermacher to Rauschenbusch, but then concludes through a constructive comparison with the polarization of thought during the era of the Arian controversy to explore the possibility of hopeful pathways forward for the evangelical church in its dual mission to both preach God's good news in Christ and to serve and care for the poor and vulnerable.
\end{abstract}

Keywords: social gospel, evangelicalism, fundamentalism, Arius, Irenaeus

Abstrak

Tulisan ini bertujuan untuk membahas pergeseran abadi dari gereja evangelis dan khususnya, Christian and Missionary Alliance Church sebagai studi kasus, menjauh dari aksi sosial aktif di akhir abad kesembilan belas dan ke arah keterlibatan yang lebih ragu-ragu selama abad kedua puluh dan hingga saat ini. BerdasarkanTimothy Moberg, tulisan ini mengakui pembalikan signifikan penekanan dalam evangelikalisme selama masa ini tetapi berpendapat bahwa akar dari pergeseran ini bukan hanya perubahan fokus tetapi sebenarnya polarisasi besar dari dasar pemikiran di dalam gereja. Tulisan ini melibatkan survei singkat dari beberapa dinamika sejarah yang terlibat yang sedang dimainkan dari Schleiermacher hingga Rauschenbusch. Namun, kemudian menyimpulkan melalui perbandingan konstruktif dengan polarisasi pemikiran selama era kontroversi Arianus untuk mengeksplorasi kemungkinan jalan ke depan yang penuh harapan bagi gereja evangelis dalam misi ganda untuk memberitakan kabar baik Allah di dalam Kristus, untuk melayani dan memelihara orang miskin dan menderita. 
Kata-kata Kunci: injil sosial, evangelikalisme, fundamentalisme, Arius, Irenaeus

\section{Introduction}

"A. B. Simpson ... in the 1880s founded the Christian and Missionary Alliance, designed especially to bring the gospel to the urban poor. . . [Simpson and his peers] founded rescue missions, homes for fallen women, and relief programs, worked among immigrants, and sought or provided jobs for countless numbers of poor people. Preaching the Gospel was always their central aim, but social and evangelistic work went hand in hand," (George Marsden). ${ }^{1}$

"The intense interest in social service on the part of early Christian and Missionary Alliance members was soon subtly opposed," (Timothy Moberg). ${ }^{2}$

The goal of this short essay is to describe the historical reasons why the evangelical church often finds itself in the second, and not the first, rank when it comes to Christian social action. This question arises from the strange situation that, at one point, Christians with an evangelical spirit were among those most committed to working out the Kingdom of God in practical ways, ${ }^{3}$ but that as the twentieth century developed, evangelicals stepped back from ministries with a primary emphasis on mercy and justice and shifted their focus toward individual evangelization and doctrinal clarity.

In the 1970's, Timothy Moberg described this shift in his important book The Great Reversal, ${ }^{4}$ which has in many ways guided the evangelical self-narrative both about what happened (a great, strange reversal) and how we ought to respond (a reversal of the great reversal). Moberg's book is very helpful, and there are others which compliment it well. ${ }^{5}$ The question that remains, however, is why, fifty or more years after diagnosing such a significant weakness in evangelicalism (the great

\footnotetext{
${ }^{1}$ George Marsden, Fundamentalism and American Culture (New York: Oxford University, 1980), 83-4.

2 Timothy Moberg, The Great Reversal: Evangelicalism and Social Concern, Revised Edition (Philadelphia: Holman, 1977), 31. Moberg's book is seminal and a very well written exposition of many of the key issues.

${ }^{3}$ Stott describes the active life of Evangelical social action extremely well in Decisive Issues, pp. 2-6. The first chapter of this book is also an excellent introduction to the topic of this paper and the current Evangelical self-narrative of 'reversal'.

${ }^{4}$ The term 'the great reversal' itself, however, was "coined by historian Timothy L. Smith." Wiebe, "The Great Reversal," 185.

${ }^{5}$ See, for example, Stott, Decisive Issues, Evans, Social Gospel, and especially Marsden, Fundamentalism, which even (in the present author's estimation) includes a few jokes in the footnotes.
} 
reversal), and agreeing on the best course of action (reversing the great

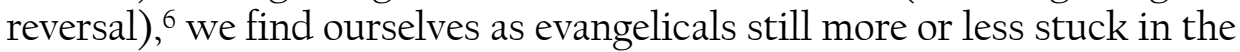
same spot: we don't always do a great job of balancing Christian social action with personal evangelization, ${ }^{7}$ and when we want to do better, we find that we don't have the resources we need-human, descriptive, practical, or theological-in order to take action.

And of course, we are taking action in part; evangelicals all over the world are making a difference and are, today, changing lives by expressing God's mercy and love in practical ways. It is exciting and encouraging to be a part of the evangelical side of God's family! If we are honest though, we must admit that, as a family, we still have room to grow in the hands-on application of the Gospel, and that our conversation about Christian social action, broadly considered, tends more toward instrumentalism ${ }^{8}$ than not. How can we do better?

\section{Method}

The method of this paper is historical reflection and comparison and has two facets. The first is to understand the historical, theological, and philosophical roots of the great polarization. In this portion of the paper, a broad survey of the history of polarization from Schleiermacher to Rauschenbusch will be followed, highlighting a possible historical track that could add to our understanding of the roots of the great polarization. The second facet goes beyond explanation and attempts to

${ }^{6}$ For example, the 'Wheaton Declaration' of 1966 (the result of a large Congress of 938 delegates from several hundred evangelical organisations and missions' boards), under the category of 'Mission and Social Concern', states that:

"In the twentieth century, many [evangelicals] have lost the biblical perspective and limited themselves to preaching a Gospel only of individual salvation without sufficient involvement in their social and community responsibilities ...

[therefore,] we urge all evangelicals to stand openly and firmly for racial equality, human freedom, and all forms of social justice throughout the world."

As a member of the Christian and Missionary Alliance church myself, I am struck especially by the fact that the one who formally presented this declaration at the Congress was none other than L. L. King, a man who would a few years later become (for a decade) the Director of Overseas Missions and then in 1978 (for another decade) the president of the C\&MA. We identified the problem, and we had a plan of action, but yet we haven't significantly reached resolution.

${ }^{7}$ We can tend toward imbalance not only considering what we do, but also how we describe or preach about what God has called us to do, and even in the manner in which we report or justify to our constituency what we have been doing and what our plans are for what to do next.

${ }^{8}$ By 'instrumentalism' here I mean the idea that Christian social action is worth our effort primarily because it is an excellent 'instrument' for opening a door to Gospel proclamation, rather than a divinely or scripturally ordained end in itself. 
find a possible heuristic solution. In this section, the method is the historical and theological comparison and description, particularly the milieu of the Arian controversy of the Church's fourth century. Special attention is paid to explaining and understanding the sociological and personal forces at play and also describing the salient elements of the solution of Nicaea and how they remain relevant in addressing our present milieu.

\section{Result and Discussion}

\section{Not (Just) a Great Reversal}

My own suggestion would be that we haven't been able to implement the solution (reversing the great reversal) because we have misidentified the problem. ${ }^{9}$ With much deference to Moberg and others, the root of our problem is perhaps not a reversal but a polarization. If reversal were really our problem situation, then resolving it would mean looking for ways to shift back toward the ground we have shifted from. But our history has shown that such a' shift back' might actually be impossible. I would suggest that the reason why we cannot simply 'shift back' is because the ground we shifted from no longer exists: that field was cut in two by a great polarization and, as a result, going back simply is no longer a possibility. Finding a better solution, then, means rediagnosing our problem situation so that we can plan a more effective course of action. Rather than interpreting our present solely in the context of our own history (a great reversal), what is needed is understanding where we have arrived in light of the broader development of Christianity in the West as a whole. ${ }^{10}$

More or less, the story runs like this."

Pre-polarized (or pre-reversed) protestant Christianity began to change forever in the eighteenth century with the arrival of the Enlightenment: the collective decision of Western society, beginning in the 1700s, to prioritize the opinions of reason, science, humanism, and philosophy. It took time, however, to work its way into the context of everyday religion.

\footnotetext{
${ }^{9}$ Fitzgerald notes similarly that "the standard account is badly in need of
} revision." The Evangelicals, 57-58. Her book originates outside the evangelical community, is exceedingly well put together, and for both of those reasons is highly recommended in helping to understand and appreciate the evangelical-liberal polarization of the early nineteenth century.

${ }^{10}$ Please see above n. 9. This broader understanding is the root of Fitzgerald's fascinating book.

${ }^{11}$ With apologies for the schematization. 
In 1781 Immanuel Kant published his Critique of Pure Reason, which remains a book of earth-shattering importance for understanding our intellectual history. Kant proposed that we only really know things in the way that they appear to us (which he called phenomena), in ways that we can see or touch or think about, and that everything else (the way things really are, in themselves, which he called noumena) is beyond the capacity of our reason. His subsequent work, the Critique of Practical Reason, built on this foundation by setting down the maxim that the best way to determine what is ethical is not to measure ourselves by an external divine law, but by reason, by thinking through what would happen if every person followed the pattern of my action as a universal rule of behaviour. ${ }^{12}$ Kant's work to this day determines many of the questions that inquiring minds ask and to which they respond, and it was decisively influential in Germany in the 1800s.

One respondent to Kant was the German theologian Friedrich Schleiermacher. In 1831 Schleiermacher published what is considered the first modern systematic theology, The Christian Faith, ${ }^{13}$ with an intentional eye toward showing that it was possible to synthesize Christian thought with modern (Kantian) philosophy, arguing that Christianity was still worth the attention of the cultured intellectual of the early nineteenth century. Within Schleiermacher's theology, our experience of faith and our ethical duty in response are not based in the idea of a God who reveals himself from above, but in the universal human experience of the 'feeling of dependency' upon God. For Schleiermacher, and for the many Christian thinkers he influenced, reason-our methodical response to the things that are within our capacity to know-can be demonstrated to be a capable foundation for both Christian reflection and ethics.

More widely recognized in the story of protestant Christianity in the West was the publication of Darwin's Origin of Species in 1859. This book provided a possible narrative for the origins of life commensurable with Enlightenment science. It took the conversation that was already taking place about using reason to anchor our understanding of the world and extended it the part of the universe we know best: ourselves. More even than the identification of scientific laws capable of describing motion, electricity, heat, and gases, Darwin's theory of evolution had the effect on many people of indicating that basically everything was explainable in a rational, scientific way.

${ }^{12}$ This principle is known as Kant's 'categorical imperative.' See his Critique of Practical Reason; also of note is his Groundwork of the Metaphysics of Morals.

${ }^{13}$ The traditional English edition of The Christian Faith is that of H. R. Mackintosh and J. S. Stewart, published by T\&T Clark, though there is a newer edition, translated by Tice and Kelsey to which I have not had access. 
At just the same time, in the German speaking world, scholars were beginning to use the tools of higher criticism to look at the Bible through a very similar lens. Representative was the publication of Julius Wellhausen's incredibly influential book, The History of Israel, in 1878. Wellhausen hypothesized that the first five books of the Old Testament were written not by Moses, but rather by four separate authors (or author groups: the Jahwist, the Elohist, the Deuteronomical, and the Priestly sources) ${ }^{14}$ ultimately compiled and redacted by an editor in the era of Ezra. Wellhausen and his school rewrote the received wisdom concerning the chronology and the authorship of both the Bible and the nation of Israel. While the conclusions of his documentary theory would today be challenged by some, the shift he embodied in subjecting the Bible to the technical criticism of the scientific method certainly remains across the spectrum of Christian biblical studies.

Alongside Wellhausen, others had started to examine Jesus himself in the same scientific and critical mode. A key contributor here was Albert Schweitzer, who in 1906 released The Quest of the Historical Jesus, in German, which aimed at carefully describing, and understanding, Jesus within his own historical Jewish context as clearly as possible. Although Schweitzer's work was a balanced response to a mixed situation, he cemented in New Testament studies the principle of using scientific principles to examine Jesus as a figure of history.

And of course, through all this, evangelicals were diligently at work, spreading God's Good News, relying on his supernatural power, reaching out at home and overseas, and making practical plans to alleviate suffering in Jesus' name wherever it was found. The Second Great Awakening ${ }^{15}$ took place within this period;the beginnings of the Holiness Movement and the founding of my own church, the Christian and Missionary Alliance, happened just as all of these events were beginning to unfold; organizations like the YMCA, the WCTU, the Red Cross, and the Salvation Army were planted and thrived with broad evangelical support; and one of the most incredible historical surges in the sending of Christian foreign missionaries took place, bringing both the Gospel and Christian mercy around the world.

But the great polarization had begun, and it was irreversible. By 1900, Christians and Christian organizations faced a decisive choice. Was the foundational principle and actor behind human experience-in knowledge (philosophy), in theology, in origins, in the Bible, and in Jesus

${ }^{14}$ Which is why Wellhausen's theory is sometimes referred to as the 'JEDP Theory'; Wellhausen included the book of Joshua in his discussion of source documents.

${ }^{15}$ The Second Great Awakening refers to the American revival of the early nineteenth century in which millions of people found truly living faith. 
himself-the winsome and powerful rationalism of the Enlightenment or the eternal and personal God, the one who uniquely and irrevocably revealed himself and acted to save humanity in the person of Jesus Christ? Of course it wasn't (usually) presented quite this starkly, and there were at that time and have been since moderates who have attempted to hold the two sides together or to find new middle ground. ${ }^{16}$ When one looks at the big picture however-the denominations, the publications, the theological schools, the Bible study tools, the parachurch organizations, the conferences, the individual believers, the music - it became clear (and remains clear today) that there were going to be two more or less homogenous groups in Western protestant Christianity, not a single, more diverse one. You see, the turn of this previous century was the pivotal season of incredible polarization in Protestantism, and it quite literally split the church - and not merely a part of it-in two. The influence of the Enlightenment finally reached a place where it couldn't simply be ignored, and Western Christians were forced to decide one way or another. And in this sudden process of polarizing, each side hardened its location and many middle ground positions simply disappeared forever. ${ }^{17}$

It was a great polarization. We can never revert back to the way that we were before, because the ground, the space of possible options which we could choose from and live out, was cleft into two pieces and reshaped.

${ }^{16}$ Donald Bloesch is a recent example, attempting to share insights from the neoorthodox movement and synthesizing them with the strengths of evangelicalism.

${ }^{17}$ As an example from my own church, A. B. Simpson, a well-read product of the 1800s, was able to approach his commentary on Genesis with great gentleness, writing that before the first day of creation it is possible that there was a "period, of whose length we are not informed, [in which] there was ample time for the geological formations which science has traced," and that "there are many things in the narrative which make [the word 'day' in Genesis chapter 1] apply much more appropriately in each instance to a long period." (Christ in the Bible, i.13-16) By 1915 however, after the polarization, George Pardington, a friend of Simpson and a significant early Alliance theologian and teacher, would follow Simpson in his comments on the order of creation, even allowing that Scripture in general uses the word 'day' to mean a literal day or a season of time, but rejects absolutely the possibility of a long process of creation: "We reject the ... mythical view and accept the literal view-the hyper-literal view.... there is no good reason for putting [creation] earlier than our accepted chronology, i.e., about B.C. 4000 years." (Outline Studies, 100). Although, in his defense, much of Outline Studies was compiled from his notes posthumously, it is characteristic of Pardington as an early post-polarization theologian to devote 25 pages of his theology text to the authority of the Bible (never mentioning the phrase 'general revelation'), 33 pages to sin and hell, and only 3 pages to the nature of God as Trinity; see also Pardington on God's justice, pp. 80-1. 


\section{After the Great Polarization}

In the years following the great polarization we learned the words liberalism and fundamentalism, and bit by bit began assigning thingsdenominations, schools, publishers, theologians, models of ministry, political initiatives- to one bucket or the other. Moody we liked, Fosdick we didn't; Princeton was out, definitely after the 1920s, but Trinity Evangelical Divinity was a good place to go; G. E. Ladd was helpful, Bultmann we wouldn't have read. Right bucket, wrong bucket. We promoted the patterns and the people in our own bucket, and pushed back against - or simply ignored - those in the other. It was like a divorce, with everything previously held in common divided among the disagreeing parties. And, basically, we never talked. We're still not really talking.

And at just that time, in the same New York where A.B. Simpson had pastored, there arose a genuine ideological giant, Walter Rauschenbusch..$^{18}$ Rauschenbusch was a Baptist pastor at the time of the great polarization, and a colossus of promoting the necessity of Christian men and women to live out the Kingdom of God through practical acts of justice and mercy, both toward their neighbours and in the structures of society as a whole. We do not often read of Rauschenbusch in the present era, but in his day, he was incredibly influential. Charles Hopkins writes that "[Rauschenbusch's] works were undoubtedly the most significant religious publications in the United States if not in the English language in the first two decades of the new century." 19 His twofold ability was his incredible passion to see the benefits of God's Kingdom be expressed to the poor matched with an outstanding ability to persuade ordinary people to join in alongside him. In Christianity and the Social Crisis (1907) and A Theology for the Social Gospel (1917) Rauschenbusch forcefully and outspokenly reminded the Church of our duty toward the poor, both individually and as constituents of our social structure.

And he was a liberal.

You see, no matter how much you agree with Rauschenbusch that both the Scriptures and Jesus himself call us to care for the poor, he is hard to read as an evangelical because he is just, well, so liberal. He asks critically: "What would Jesus have said to the symbol of Chalcedon?"20 Regarding the cross he comments that "the effect of the atonement on God is that of a critical event to solidify his good will toward men in that

${ }^{18}$ Rauschenbusch ministered in the same neighbourhoods as A. B. Simpson in the 1880s. See "The Social Gospel vs. Personal Salvation," by Daniel J. Evearitt.

${ }^{19}$ Charles Howard Hopkins, The Rise of the Social Gospel in American Protestantism: 1865-1915 (New Haven: Yale, 1967 (1940)), 216.

${ }^{20}$ Walter Rauschenbusch, A Theology for the Social Gospel (Nashville: Abingdon, 1945 (1917)), 25. 
Christ had died so well ... [with the result that] the experience of the cross reflected directly upon the mind of God."2l The atonement, he writes, "furnishes a mystic basis for the social revolution." 22 His theological positions are extravagantly grounded in the Liberalism of his age: reason and our experience guide the interpretation we give to the story of God at work in Christ and spur us to act. From an evangelical perspective, Rauschenbusch was not merely theologically unpalatable, he was an impossibility. He was in the other bucket if anyone was, and so was everything that had his aroma on it. That was how we decided to divide things up. And so, because Rauschenbusch was Christianity's chief ambassador for the importance of Christian social action, that went in the liberal bucket too, and it has pretty much stayed there ever since. ${ }^{23}$

That's the story. The reason that we have so much trouble thinking about - and doing-Christian social work in the evangelical church is that at the time of the divorce the most potent expositor of God's justice happened to be substantially wrongheaded theologically. The world became polarized, and mercy ministries were very publicly deposited in the other bucket. We responded, a bit, with the instrumentalist rationale that social Christianity could be of value if it opened the door to Gospel presentation (which it does), but never got back the idea that Christian charity requires, well, Christian charity, as carefully and effectively as we can offer it, both toward individuals and within systems.

You see, at the end of the day, it didn't matter that Rauschenbusch was actually right regarding our duty to the poor. It didn't matter because he was in the other bucket, and so for a century we have kept from saying any of the things which he had said lest we get put in that bucket too. What a problem. How do you get back something that you mistakenly gave away in a divorce?

\section{A Lesson from Church History}

The good news is that although the ground has shifted, it is not impossible for us to retrieve what we have lost, at least in part. The early 1900 s were by no means the only season of great polarization in the history of the Church, or near-polarization. Consider especially the

${ }^{21}$ Ibid., 264.

22 Ibid., 267.

${ }^{23}$ Marsden describes this situation by noting that "when fundamentalists began using their heavy artillery against liberal theology, the Social Gospel was among the prime targets. In the barrage ... it was perhaps inevitable that ... their own progressive social values would become casualties." George Marsden, Fundamentalism and American Culture, 91. 
near-polarization of the Church regarding the doctrine of the Trinity in the third and fourth centuries.

The New Testament is clear: God is one God, and Jesus is Lord. That's what the apostles taught and what the early Church taught. Of course, they didn't employ the creedal definitions that we now (rightly) find invaluable because their intellectual ground was different; their world was pre-polarized. The earliest Fathers didn't use the language of three Persons and one Substance, but not because they would have objected to that kind of language; it simply was unnecessary for them. And so you can find Irenaeus (late second century) standing up for the Christian faith, describing how the Son and the Spirit participated with the Father in our creation, saying that "God shall be glorified in His handiwork ... for by the hands of the Father, that is, by the Son and the Holy Spirit, man, and not merely a part of man, was made in the likeness of God." 24 Nowadays no one would say it like that; it would be seen as lowering the Son and the Spirit to the level of tools under the direction of the Father. At the time, however, it was unproblematic because, for Irenaeus, pre-polarization, the equality of the divine persons was presumed.

But in the third and fourth centuries the situation changed, becoming polarized due to a charismatic church leader with a gigantic influence: Arius. Arius is remembered as one of the arch-heretics of the early church, and he certainly was, but he was grappling with a real question.

Arius, in struggling to see how God could be one God if both Father and Son were fully and equally divine, looked for a different way forward. He recognised, like Irenaeus, that the Father and the Son have different roles in God's economy of salvation, but his unique (and wrong) deduction was to go one step further and determine that having a different role meant having a different category of being. For Arius, a different role meant existing on a different level, or having a different kind of divinity. Arius depicted this difference between the Father and the Son by suggesting the Father has always existed, but that there was a time (or a something) when the Son did not exist. The Son was God's first, divine, excellent creation, and through the Son he created all things: the Son was divine, and excellent, just not divine in the same way that the Father was. After all, he had a different (lower) job, right?

Arius nearly split the church by trying to introduce a split right into the Godhead, right between Father and Son. Full divinity gets put in

\footnotetext{
${ }^{24}$ Irenaeus, Against Heresies, Translated by A. Cleveland Coxe. In Ante-Nicene Fathers, volume 1. Edited by Alexander Roberts and James Donaldson (Peabody, MA: Hendrickson, 1994 (1885)), 5.vi.
} 
the bucket where we keep all the things that go with the Father, and another really good divinity-but a little bit less, or a different one-goes in the Son's bucket. Then it all makes a little more sense. And each of us will decide where we put ourselves. Some will go with the group that is following Arius, and some others for the group that says that Father and Son are exactly equal in divinity. The middle ground evaporated.

Arius was both popular and personable, but the church rejected his division, though it was a long journey to get there. To continue the analogy, if there were going to be buckets for the Father and the Son, the exact same thing has to go in each bucket. The Nicene Creed (325) is the systematic response of the Church to the error of Arius: a different role does not necessitate a difference in value, or worth, or anything else. God the Father is the "Maker of heaven and earth," and God the Son is the one "by whom all things were made," and "who, for us men and for our salvation, came down from heaven, and was incarnate by the Holy Ghost and the virgin Mary, and was made man; and was crucified also for us under Pontius Pilate." ${ }^{25}$ Yes, there is no questioning or denying that Father and Son (and Spirit) have different roles, but that is only said in the context of simultaneously declaring their radical equality. The Lord Jesus Christ, in the Creed, is "begotten of His Father before all worlds, God of God, Light of Light, very God of very God, begotten, not made, being of one substance with the Father." 26

The Nicene definition of the Trinity is a reason for great optimism; it's an example of re-finding unity after a season of extreme polarization. But it cautions us to be realistic as well. After Arius we can never go back to living in the world of Irenaeus and the Son and Spirit as the two hands of God ever again. Shifting back is impossible, but redemptively shifting forward is. In regard to the problem of this paper, evangelical social action, Nicaea also contains the kernel of the way forward.

You see, Nicaea crystallized one of the astronomically significant and counter-intuitive distinctives of Christianity: in God's economy, having a different role does not mean having a different value, and let us never try to draw our fingers down that line in the sand. The Father's role is different than the role of the Son, to be sure, and we don't need to avoid mentioning that: the Father is always the sender; the Son is always the sent one. But at the very same time, "the Father loves the Son, and has put everything into his hands." ${ }^{27}$ "And he is God, the one who rules over everything and is worthy of eternal praise! Amen." ${ }^{28}$

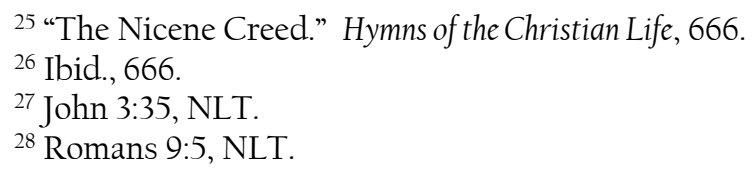


And what is true about the value of the heavenly Persons in spite of the difference in their roles is true of us in the church as well: having a different role never means getting assigned a different value or having a different level of worth. ${ }^{29}$

\section{Conclusion: Getting Social Action Back in the Right Bucket}

All of which brings us full circle. As John Stott says, "it is exceedingly strange that any followers of Jesus Christ should ever have needed to ask whether social involvement was their concern." 30 But we do. We grew up in a world where it wasn't in our bucket. In one sense, it seems like we should just be able to take that one step back to where we once were, to a pretty good balance of evangelistic and social ministry, but we can't. That ground where we used to stand simply doesn't exist anymore, and the resources and ideas that we once used to explain social Christianity no longer have any footing. A great polarization happened, and whether we like it or not we are on this side of it, not the other one. Reversing the great reversal is no longer a possibility.

But getting our stuff back is. And I want it back. Many of us do. How? How do we do it? I tend to think that one of the tools we can start with is that same old Nicene Creed we had all along. You see, having different kinds of roles, different jobs, is just the kind of thing that God intentionally likes to make happen for us. It's what God has chosen for his own being and action. And remember Irenaeus? 'By the hands of the Father, that is, by the Son and the Holy Spirit, we, and not merely a part of us, were made in that likeness.' We are made in the image of that triune God, among whose Persons difference of role never means difference of value or importance or priority. In the Godhead, one Person, one role, does not ever exist only so as to make possible the ends of another; each, united in perfect mutual love, is an end. That is the image in which we are created.

And so it is should never amaze us to discover that some others in God's family are themselves quite different, have been given quite a different role by God, and yet, "we are members of one another." 31 Christian social action has been out of our bucket for so long that we don't really even have a place for it anymore, so it will feel surprising when we politely reach into that other bucket and bring a portion of it back into our own. ${ }^{32}$ It will also be uncomfortable.

${ }^{29}$ Compare 1 Corinthians 12:14-26.

${ }^{30}$ John Stott, Decisive Issues, 2.

${ }^{31} 1$ Corinthians 12:27.

${ }^{32}$ I am very thankful to those of my brothers and sisters with whom I disagree on some theological issues, even significant ones, for their effort in guarding and 
But you see, if the One who is God from God, Light from Light, and is of one being with the Father, came down from heaven for us and for our salvation, and was incarnate and crucified for us-if he could do something so very different from the Father and yet remain very God of very God, then perhaps we may find that he has planned different-but equally important-roles for you and for me, and that in each of them you and I will serve his Kingdom together according to his providential will. In fact, "shouldn't we expect far greater glory under the new way, now that the Holy Spirit is giving life? ... and [as] the Lord-who is the Spirit-makes us more and more like him as we are changed into his glorious image," 33 the image of that same Son. That's where it seems we could begin. ${ }^{34}$

[An abridged version of this article first appeared in, and is an excerpt from, the book entitled Hands: Stories and Lessons of Wholistic Development.]

\section{Bibliography}

Darwin, Charles. On the Origin of Species by Means of Natural Selection, or the Preservation of Favoured Races in the Struggle for Life. London: John Murray, 1859.

Evans, Christopher H. The Social Gospel in American Religion: A History. New York University, 2017.

Evearitt, Daniel J. "The Social Gospel vs Personal Salvation: A Late Nineteenth-Century Case Study-Walter Rauschenbusch and A.B. Simpson." Alliance Theological Review (1997).

http://www.kneillfoster.com/aar/1997/AAR1997-3.php.

Fitzgerald, Frances. The Evangelicals: The Struggle to Shape America. New York: Simon and Schuster, 2017.

Grounds, Vernon C. Evangelicalism and Social Responsibility. Scottsdale, PA: Herald, 1969.

Henry, Carl F. H. The Uneasy Conscience of Modern Fundamentalism. Grand Rapids: Eerdmans, 1947.

Hopkins, Charles Howard. The Rise of the Social Gospel in American Protestantism: 1865-1915. New Haven: Yale, 1967 (1940).

nurturing this ministry of Christian social action even when my own side of the Christian family has neglected it.

332 Corinthians 3:8, 18, NLT.

${ }^{34}$ Special thanks are due to the staff at Ambrose University library in Calgary, Canada for their continual and open-handed help and encouragement. They (and the collection) are a gift to the church; it is a place that for me has always felt like home. Thank you. 
Hymns of the Christian Life. Harrisburg, PA: Christian Publications, 1978.

Irenaeus. Against Heresies. Translated by A. Cleveland Coxe. In Ante-Nicene Fathers, volume 1. Edited by Alexander Roberts and James Donaldson. Peabody, MA: Hendrickson, 1994 (1885).

Kant, Immanuel. Critique of Practical Reason. Translated by Mary Gregor. Cambridge, 2015 (1788).

. Critique of Pure Reason. Translated by Paul and Allen Wood. Cambridge, 1999 (1781).

. Groundwork of the Metaphysics of Morals. Translated by Mary Gregor and Jens Timmermann. Cambridge, 2012 (1785).

Marsden, George. Fundamentalism and American Culture: The Shaping of Twentieth Century Evangelicalism, 1870-1925. New York: Oxford University, 1980.

Moberg, David O. The Great Reversal: Evangelicalism and Social Concern, Revised Edition. Philadelphia: Holman, 1977 (1972).

Noll, Mark A. A History of Christianity in the United States and Canada. Grand Rapids: Eerdmans, 1992.

Pardington, George P. Outline Studies in Christian Doctrine. Camp Hill, PA: Christian Publications, 1996 (1915).

Rauschenbusch, Walter. A Gospel for the Social Awakening: Selections from the Writings of Walter Rauschenbusch. Edited by Benjamin E. Mays. New York: Association Press, 1950. . A Theology for the Social Gospel. Nashville: Abingdon, 1945 (1917).

Schleiermacher, Friedrich. The Christian Faith. Translated by H. R. Mackintosh and J. N. Stewart. T\&T Clark, 1968 (1831).

Schweitzer, Albert. The Quest of the Historical Jesus. Translated by W. Montgomery. London: Macmillan, 1954 (1905).

Simpson, A. B. The Christ in the Bible Commentary, volume l. Camp Hill, PA: Christian Publications, 1992.

Stott, John. Decisive Issues Facing Christians Today, Second Edition. Old Tappan, NJ: Revell, 1990 (1984).

Wellhausen, Julius. Prolegomena to the History of Israel. Translated by J. Sutherland Black and Allan Menzies. Cambridge: 2012 (1878).

Wheaton Declaration. Declaration of the Congress on the Church's Worldwide Mission. Wheaton, IL: Evangelical Foreign Missions Association, 1966.

Wiebe, Katie Funk. "Book Review: The Great Reversal: Evangelism Versus Social Concern.” Direction 3, no. 1 (April, 1974), 185-6. 